\title{
Credibility and Signaling as Strategic Drivers in China's African Security Engagement
}

\author{
Fanie Herman \\ Graduate Institute of International Politics, National Chunghsin University, Taichung, Taiwan, China \\ Email: tokkief@yahoo.com
}

Received 10 January 2015; accepted 26 January 2015; published 11 February 2015

Copyright @ 2015 by author and Scientific Research Publishing Inc.

This work is licensed under the Creative Commons Attribution International License (CC BY). http://creativecommons.org/licenses/by/4.0/

(c) (i) Open Access

\begin{abstract}
The aim of this paper is to show that strategic interaction provides a fruitful way to understand China's decision-making behavior. States are actors in global politics and frequently have to make choices that are strategic. Credibility and uncertainty are central issues in this environment of incomplete information. This raises the question how China signals its motivations along this strategic chessboard. Strategic interaction assumes purposeful behavior from China in the African security environment. Signaling allows China to consider the problem of unknown motivations, making choices based in part, on what other actors are likely to do in the future. Knowing the choices of other African actors can help China judge what likely responses are.
\end{abstract}

\section{Keywords}

China, Strategic Interaction, Credibility, Signaling, Motivations

\section{Introduction}

States are often assumed to be rational or "purposive" actors, pursuing various objectives understood to be consistent with their separate interests (Viotti \& Kappi, 2012: p. 74). Within the global system, there are opportunities that can help achieve specific objectives, if handled properly (Viotti \& Kappi, 2012: p. 75). Similarly, states have to be willing to implement strategies to deal with the achievement of basic objectives (Jervis, 1976). However, in order to exploit these opportunities and show a willingness to cooperate or defect, states are required to mobilize the various capabilities they have at their disposal in order to exert power constructively to achieve those objectives and protect those interests (Jervis, 1976). States that send peacekeepers to conflict zones have to take the elements of threat and vulnerability into account before they can implement measures to counter these operational constraints. These measures take the form of protecting their own interests, alertness not to deplete available resources and of particular importance, and intention as a source of threat between what decision mak- 
ers perceive as threatening and what the evidence and military capabilities suggest (Jervis, 1976). Privately held information creates uncertainty in this context; states at times have an incentive to misrepresent information about their capabilities and their intentions (Fearon, 1995: p. 382).

Any strategic plan by a state to achieve objectives must ultimately be judged in terms of its empirical utility (Lake \& Powell, 1999: p. 20). The question is: how well does China understand the African security environment and does the strategic setting of choices hold the promise of an important intermediate payoff? This paper attempts to answer the latter question by focusing on signaling as strategic problem in China's security interaction. Credibility and uncertainty are at the heart of this strategic problem and shed light on a state's likely choices when making strategic decisions (Morrow, 1999: p. 80). Signaling also affects China's economic goals, diplomacy and stance on other social issues, such as human rights and humanitarian intervention. Therefore, the first part examines China's actions as a credible actor in the African security environment, while the second part addresses the problem of strategic signaling. The question is if China knows something of relevance to other actor's decisions and attempts to reduce the cost. A case study on China's African peacekeeping operations (PKOs) is presented in the third part to support the arguments in this paper.

\section{Credibility in an Uncertain Environment}

Morrow (1999: p. 79), formulated the following set of questions: first, can parties signal one another about their motivations? In other words, is it in an actor's interest to disclose to another its precise goals, and for the latter to believe that disclosure? China as part of a multinational task force operates in the peacekeeping environment without always possessing complete information about the other countries motivations. This raises the question of uncertainty how to react to environmental constraints, such as, dealing with humanitarian assistance in the Democratic Republic of the Congo (DRC) and interpreting human rights in a conforming fashion with other contingents in Sudan-Darfur.

As dynamic interaction increases, the question of credibility is raised. Although an actor may promise to take certain actions in the future, will those actions be in its interest if the time comes to live up to its promise (Morrow, 2009: p. 80)? If those actions may prove to be contrary to its interest, other actors doubt the credibility of the promise. What promises does China make with regards to securing a safe and peaceful African environment? Are these actions beneficial to its interests and can China keep up with the promises in the immediate and long run? China's African Policy and the Forum on China-African Cooperation (FOCAC), point out some of its intentions to cooperate in the security area. It also addresses the dynamic interaction issue (Shinn, 2012).

An attempt by China to indicate its willingness to establish credible signals is an important part of the strategic setting of choices. If China accurately and completely represents privately held information, the outcome of possible confrontations with other security seeking states in the region would be minimized or totally avoided. China is not purely interested in its own security but is also wary of other state's rising security, as the growth of power in a state such as India, which is also actively involved in African PKOs, can make China's power less secure. This line of reasoning is based on the paradox of the security dilemma. According to neorealist theory, all states are interested in security (Waltz, 1979: p. 118, 126). If all states were interested only in such preservation and their sole interest in security was known to all, not state would pose a threat to any other; all can maintain their position by upholding the status quo. Because all are interested only in security and all know that no state need fear that another will attempt to overturn the status quo (Morrow, 1999: p. 79). Nevertheless, China is concerned about other's power and policies. Even if the peacekeeping environment is conducive to maintaining a position of power and presents opportunities to expand power, China decision makers cannot be certain that others will exert less power to maintain their positions or even to moderate revisions of the status quo. Rational accounts of the security dilemma emphasize the signals that states send and on the formulating of credible commitments rather than on the perceptual dynamics of the perceiver (Gross-Stein, 1985: p. 66).

Security cooperation with African states, suggests that China wants to maintain a security presence in the form of peacekeeping, and deliver promises that are beneficial to its Africa interests. Both China and African players view these promises as of reciprocal value and are diverse across the political spectrum. For example, promises in the forms of loans, aid and development programs in post-conflict societies are returned in kind by the diffuse concept of reciprocity. Diffuse reciprocity points to a wider institutionalization of trust, through consistent cooperation in international society (Keohane, 1986: p. 9). Through continued involvement in PKOs, China is seen as building generally accepted standards of behavior that exert a normative pressure on the actions 
of China to develop long-term obligations and stress cooperation. Thus, in this system of diffuse reciprocity, China needs not to seek immediate benefit guaranteed by specific reciprocity, such as in trade negotiations, but can act in confidence that PKOs in the long run will be repaid by post-conflict societies seeking closer cooperation.

In order to strengthen capacity, China looks forward to strengthening cooperation with African States and sub-regional organizations in the areas of logistics (Wang Wei, 2010). China also said it will continue to strengthen its cooperation with the African Union (AU) and sub-regional organizations and institutions, support the AU's leading role in resolving African issues, and take an active part in UN peacekeeping operations in Africa in the Forum on China-Africa Cooperation Beijing Action Plan (2007-2009) in 2006 (Wang Wei, 2010). The Chinese government made a promise again in Forum on China-Africa Cooperation Sharm el-Sheikh Action Plan (2010-2012) in 2009. It pledged it would continue to support the UN Security Council in playing a constructive role in solving conflicts in Africa and continue to support and participate in UN peacekeeping missions. It intended to strengthen cooperation with countries concerned in the UN Peace Building Commission and support countries in their post-war reconstruction processes (Wang Wei, 2010). Inferring from the above information it becomes evident that China wants to elicit a belief among African actors, which include the post-conflict societies, that it has the qualities, capabilities and power of being believable or worthy of trust, thus being a credible actor. Credibility refers to the objective and subjective components of believability of a source or message (Bocking, 2004: p. 164).

What credible choices can China make? The argument is that future choices cannot be fixed in advance and oftentimes has to be made without delay or in a position demanding quick response or action. Non-cooperative game theory models credibility issues in the sequence of moves in a game (Fearon, 1995: p. 383). Making the right moves with regards to security cooperation in Sudan-Darfur is of paramount importance to protect Chinese interests. Strategic interaction in this environment is sequential, meaning that China decision makers first consider the moves of the Khartoum government and then choose an alternative. It is in this instance where the issue of credibility rises again: the incentive is to protect China's oil interests and induce the government of Juba (The Republic of South Sudan) to make a particular move, for example, granting more oil concessions in return for development assistance and financial aid. On the other hand, Juba cannot be sure if China's promise of development is a reliable guide to its future behaviour. Credibility in this instance has recourse in the statements made by leaders of China and Sudan-Darfur and vested in future course of interaction. What do both players think the other player will do in the future? China's peacekeeping motivations in broad terms are known to the general public and international observers. What is not revealed is that certain motivations may be unknown and this is where the strategic problem of signaling comes into the picture. An actor's motivation is also called its type and based on choices what other actors are likely to do in the future (Fearon, 1995: p. 386). Other strategic players in the African strategic security environment have a way to judge China's motivations if they know what these motivations are.

\section{Signaling}

\subsection{The Separation of Types}

The strategic logic of signaling allows other actors to infer from the actions China make and confer a certain type to these actions. China's African PKOs which centers on portraying a certain image of the country and displaying the "goodwill intent" of the peacekeepers, usually conforms to the same standard or rule and is said to be constant over a period. However, the strategic logic of signaling depends on the separation of types (Frieden, 1988: p. 63). What is true is that China's actions differ in situations and depends on its own motivations and strategic setting. For example, peacekeeping in Liberia not only has the goal to separate warring parties but also serves as an intermediary channel to attract Liberian nationals to learn more about Chinese language and culture. Another incentive is to increase opportunities for Liberians to possibly find work and study in China (PayeLayleh, 2009). In other African peacekeeping areas the motivation might be different as the next report indicates: "Senior African Union and UN officials believe that China participation in peace operations in sensitive areas such as Darfur, southern Sudan and the DRC helps to temper the host governments' suspicions that the missions are really Western-led military interventions” (Ghosh, 2009). It is however, a false claim to assert that Chinese actions intentionally follow the example of other types in order to mislead the receiving party what the motivations are. Chinese actions are also not pooling. When types take the same action they are said to pool, and others 
can learn nothing new about their type from that action (Morrow, 1999: p. 87).

One aspect of the separation of types that conforms to Chinese practices is the alleged sincerity with which tasks are accomplished and the positive feedback from local populations. During President $\mathrm{Hu}$ Jintao's visit to Sudan in 2006, he vowed that Chinese peacekeepers are "sincere" in supporting Africa to achieve peace and stability with concrete actions and that Africa can rejuvenate with the assistance given by China (The Embassy of the People's Republic of China in New-Zealand, 2006). In addition, African post-conflict societies also view the Chinese actions as sincere, as reports and public statements on the goodwill intentions of peacekeepers illustrate (Ghosh, 2009). This perception may however be subjective to project a favorable image of the peacekeepers and separate them from other contingents. The Chinese media is a very effective propaganda instrument to sway the perceptions of local populations in mission areas. The Indian and Pakistani troops are also praised and categorized under identical performance assessments by UN staff and local populations. They are however typed as non-conformative to Chinese actions and procedures.

\subsection{Signaling and Costs}

Are there costs involved in the actions of Chinese PKOs? A type can signal its intentions by taking actions that inflict costs it is willing to bear but other types are not. Costly signaling is the common term for the idea that costs can separate types (Morrow, 1999: p. 88). What are the costs China is ready to consent or undertake with African PKOs? Cost implies that there must be a price or reward, which can be seen as a loss or sacrifice or effective in relation to the goal that is pursued. Peacekeeping remains a highly cost-effective instrument in progress towards lasting stability because no other international tool is as effective in combining political, security, rule of law and human rights efforts (Huang \& Gill, 2009). This undertaking means that there is a cost-effective relationship in the efforts of China. A surely beneficial cost in the establishment of future stability is to be credible in the eyes of the people you're supposed to protect and creating conditions for building trust and confidence.

Efforts should not only be concerned with monitoring ceasefires and peace processes, but may include a range of extra activities, such as, the strengthening of national security sectors, the implementation of programs to reintegrate ex-combatants into civilian life, the strengthening of rule of law, reconciliation and inclusive political processes, protection of civilians and their rights, building of governance institutions and delivery of humanitarian aid (China.org.cn, 2013). These are all efforts that will be cost-effective to China in the long-run as it will secure interaction with local players, bring sustainability in business relationships and strengthen diplomatic ties. China will want to avoid costs that separate itself from the environment and would rather focus on costs that are beneficial to all parties. The prospect of different costs from different actors can create a separation of types and in the worst case scenario lead to perceptions of threat. What about other countries imposing costs on China to perform in the peacekeeping environment? Members of the emerging economic block of Brazil, Russia, India and South Africa (BRICS) produce costs on China to create favorable conditions for trade and business ventures. Through being engaged in large peacekeeping deployments, China levels the political and economic playing field for these players to successfully enter the business environments. China benefits from these costs because it allows Beijing to demonstrate that it is interested in establishing peace and stability. Audience costs are one way actors can separate their type and convince others of their motivations (Morrow, 1999: p. 89). These audiences could be domestic or foreign; the key point is that they are not the intended recipients of the signal and purely derived from the actions of the side the sender is trying to inform (Fearon, 1995: p. 383).

Costless signals can help actors coordinate their actions when multiple acceptable courses of action are available and lead decision makers to decide which course of action to adopt. This is the last type of cost that produces a capacity for understanding China's separation of types. Acting in accordance with the rules of UN peacekeeping resolutions, an example is given of such costless signals in action. The act of voting on such resolutions does not inflict harm to China's willingness to contribute to PKOs, because such decisions are executed in relation with other role-players and coordinated in manner which is mutually inclusive to all the parties concerned. Signals that are not credible can impair China's ability to assess threat perceptions and create a situation of foregone engagement. What is taking place in China's PKOs, in general, is a good reflection of its attitude to the outside world and contains a cacophony of mixed signals (Ogorodnev, 2012). Rationalist explanations of threat perception focus on the dilemmas that the sender of the signals, in this case, China, might confront in formulating credible commitments. Commitment is a problematic issue because actors often want to make 
promises that others doubt the actors will be willing to carry out later (Morrow, 1999: p. 91). Players will believe the promises China makes if the latter is committed and they have no reasons to doubt that China will carry out actions that are in their interest. If China reneges on the promises it makes, such as, providing loans and scholarships to recipients in troubled societies, Africans may view these commitments as not credible and choose actions that compromise negotiations and cooperative programs. The divided perceptions Africans have toward Chinese peacekeepers in Sudan-Darfur illustrate the dynamics of threat perception by those who are the target of the signal.

\subsection{The Logic of Separation}

The logic of signaling implies logic of perception; signals that are sent acquire meaning when they are perceived (Jervis, 2002: p. 297). This kind of misrepresentation and deceptive signaling is most likely to occur when the credibility of threats is a primary concern of the sender rather than the perceiver (Jervis, 1978: p. 170). Credible commitments are important because they are markers of the future, a signpost which leaders can use to assess intentions and threat not only in the present but in the future (Mercer, 1996). Because there is a deeper side to any story than the evidence that exists on the surface, the argument is that China not only employs peace- keeping as an extension of its security engagement with African nations but also pretending to have strength and knowledge to bring about peace and stability, when, there is a possibility that it is lacking resolution to make credible commitments. China can create certain means for misunderstanding if it does not use the immense resources at its disposal to the best advantage of all the relevant players. This failure to deliver on implicit promises can lead to conflict between the decision makers and the people it has to protect in peacekeeping zones.

These arguments on threat perceptions are important because they are indicative of future behavior, showing the direction decision makers have to take in assessing intentions. In addition, the difficulty of making credible commitments can complicate signaling for China and increase the threat perception among African states, which are also seeking security and restraint by factors on the system level of analysis. Establishing secure and conflict free societies, after all, are one of the main goals for peacekeeping intervention by any country. If the citizens of these societies perceive China as a threat, it will be a troublesome task for decision makers to formulate policies that facilitate cooperation.

\section{Case Study: Credibility in Peacekeeping}

In post-conflict societies the credibility of China's PKOs are assessed in three ways. First, the actions of the peacekeepers are observed in accordance with established practices. These habitual actions take the form of rules and regulations under specific mission mandates and the general ethical considerations under which peacekeepers are supposed to act (Gosset, 2012). Trade, finance, business and tourism are all areas in which China's global projection is having a considerable impact but international peacekeeping efforts are some of the most promising forms of the country's opening-up to the world. Not well known or fully appreciated outside China, it illustrates the country's willingness to be a globally responsible actor (Gosset, 2012).

The second credibility factor refers to expertise which is subjectively perceived by all the parties to the peace process (Gosset, 2012). These include the victims of the conflict, local populations who are in direct contact with peacekeepers and those who stand on the sideline, soldiers who are engaged in combat, government structures and officials, and foreign observers. In this instance, onlookers view the credentials of the peacekeeping contingents and their status. Chinese troops which have already earned various medals and awards by the United Nations Department of Peacekeeping Operations (UNDPKO) and mission leaders build on this reputation to project a further image of expertise.

Another component that adds credibility to the Chinese presence is information quality, which is derived from media reporting on PKOs (Flanagin \& Metzger, 2008: p. 13). Chinese troops are praised for their contributions in repairing infrastructure, providing medical assistance and interaction based on social and educational programs. The Confucius institute in Liberia is an example of an institution which has a marked effect in conveying Chinese culture and language to an African audience. The concept of perfection also adds credibility to information quality. Strategies are perfect if every move is in the moving player's interest when he or she must make the move, given all the future moves of the game. If a promise satisfies the test of perfection, then the promise is credible (Axelrod, 2006).

Current Chinese peacekeeping actions are based in part on past behaviour. Lessons are learned from interven- 
tions in other conflict areas, such as, Lebanon and Haiti and applied in the African peacekeeping context. This is not an impossible task, as the task carried out by peacekeepers follows certain codes of conduct and what bears fruit in one area can also be applied with success in another area. The tactics might differ but the overall objective is the same. The situation in Sudan is one example where actors agreed in principle on the promises China made to avoid punishments from the agreement and this is a situation where sequence matters. Thus, reciprocal threats, is a strategy states can employ in situations that are repeated (Axelrod, 2006). Because of China's closed political system and secrecy with regards to revealing primary information (detailed government reports and insiders accounts on formal decision making processes), other players are uncertain about its motivations. Games of incomplete information specify this uncertainty (Morrow, 1999: p. 83). China’s payoffs, for example, could be its private information that it withholds from other players to make strategic moves beneficial to only its own interests and not of reciprocal value. This private information determines its type, as the other players get to know the characteristics of the player, the chance each type will occur in a specific situation and what its future actions might be (Morrow, 1999: p. 84). Other players may be unsure how to interpret China private information which raises the uncertainty factor.

\section{Conclusion}

Strategy is fundamental to the study of Chinese engagement in the African security landscape. Signaling is central to the strategic-choice approach. This problem moves China to produce certain outcomes resulting from uncertainty in the environment. What China does now also depends on what other countries will do later, and the former has a good reason to doubt the latter's promises about that future move. Signaling directs us to focus on parts of China's strategic setting of choices in the security environment and not on all the facets of security related matters. Precisely because there are multiple strategic problems in security issues, the expectation is not to find an explanation to account for all the events of security cooperation. This paper pointed out that China's realization of strategic outcomes can assist with defining a comprehensive strategy for security cooperation and particularly its participation in PKOs. Currently China's actions appear to center on rational decision making by the leadership and on specific case studies. China's security engagement in Africa is a natural extension of its foreign policy. In order to make credible commitments and strengthen this foreign policy, domestic politics have to be taken into account. The argument is that domestic politics can serve as a source of the costs that makes China's signals credible. The multitude of Chinese companies operating in the African business environment has the ability to influence decisions taken by the leadership and higher echelons of decision making. In addition, these companies face huge strategic problems in the African strategic marketplace and with resources, and skills have the ability to unpack strategic problems that occur in the African security arena. In other words, a general understanding of state and domestic politics can help the leadership to reduce uncertainty and be less concerned about sending wrong signals. What can be said is that the characteristics of the strategic environment move the leadership to act in a certain way, signaling an intention to assert a stronger security and military presence and presumably displaying an image of a credible actor. Finally, the analysis indicates that China is increasingly starting to understand the security environment, not only to achieve its economic objectives but also to pursue a foreign policy that is compatible with the African context. The strategic setting of choices holds the promise for such an important intermediate payoff.

\section{References}

Axelrod, R. J. (2006). The Evolution of Cooperation. United States: Basic Books.

Bocking, S. (2004). Nature's Experts: Science, Politics, and the Environment. New Brunswick, NJ: Rutgers University Press.

China.org.cn (2013). UN Chief Lauds Peacekeeping as Cost-Effective Investment in Lasting Stability. http://www.China.org.cn/world/Off_the_Wire/2013-01/22/content_27754500.htm

Fearon, J. D. (1995). Rationalist Explanations for War. International Organization, 49, 379-414.

Flanagin, A. J., \& Metzger, M. J. (2008). Digital Media and Youth: Unparalleled Opportunity and Unprecedented Responsibility. In J. Miriam, \& A. J. Flanagin (Eds.), Digital Media, Youth, and Credibility (pp. 5-28). Cambridge, MA: The MIT Press.

Frieden, J. A. (1988). Sectoral Conflict and U.S. Foreign Economic Policy: 1914-1940. International Organization, 42, 5990.

Ghosh, T. (2009). China’s Expanding Peacekeeping Role. 
http://panos.org.uk/features/Chinas-expanding-peacekeeping-role/

Gosset, D. (2012). China a Trustworthy Peacekeeper. http://www.operationspaix.net/DATA/DOCUMENT/7496 $\sim$ China_a_trustworthy_peacekeeper.pdf

Gross-Stein, J. G. (1985). Calculation, Miscalculation, and Conventional Deterrence: The View from Jerusalem. In R. Jervis, \& N. Lebow (Eds.), Psychology and Deterrence (pp. 34-59). Baltimore: John Hopkins University Press.

Huang, C. H., \& Bates, G. (2009). China Expanding Peacekeeping Role. http://books.sipri.org/files/PP/SIPRIPP25.pdf

Jervis, R. (1976) Perception and Misperception in International Politics. Princeton: Princeton University Press.

Jervis, R. (1978). Cooperation under the Security Dilemma. World Politics, 30, 167-214. http://dx.doi.org/10.2307/2009958

Jervis, R. (2002). Signaling and Perception: Drawing Inferences and Projecting Images. In K. R. Monroe (Ed.), Political Psychology (pp. 293-312). Mahwah, NJ: Lawrence Erlbaum Associates.

Keohane, R. (1986). Reciprocity in International Relations. International Organization, 40, 1-27. http://dx.doi.org/10.1017/S0020818300004458

Lake, D. A., \& Powell, R. (1999). Strategic Choice and International Relations. Princeton, NJ: Princeton University Press.

Mercer, J. (1996). Reputation and International Politics. Ithaca, NY: Cornell University Press.

Morrow, J. D. (1999). The Strategic Setting of Choices: Signaling, Commitment, and Negotiation in International Politics. In D. A. Lake, \& R. Powell (Eds.), Strategic Choice and International Relations (pp. 77-114). Princeton, NJ: Princeton University Press.

Ogorodnev, I. (2012). Peacekeeper Menace: Pentagon Sees Chinese UN Missions Threats. http://rt.com/news/China-us-congress-peacekeeping-631/

Paye-Layleh, J. (2009). Learn Chinese for Free... in Liberia. http://news.bbc.co.uk/nol/ukfs_news/hi/newsid_8290000/newsid_8297500/8297557.stm

Shinn, D. (2012). May 15, China Security Policy in Africa and the Western Indian Ocean. http://davidshinn.blogspot.com.tr/2014/12/chinas-growing-security-presence-in.html

The Embassy of the People’s Republic of China in New-Zealand (2006) Li Zhaoxing Talks of President Hu Jintao’s TourA Successful Journey of Friendship and Cooperation. http://www.Chinaembassy.org.nz/eng/xw/t297725.htm

Viotti, P. R., \& Kauppi, M. V. (2012). International Relations and World Politics: Security, Economy and Identity. Englewood Cliff, NJ: Prentice Hall

Waltz, K. (1979). Theory of International Politics. Reading, MA: Addison Wesley.

Wang Wei (2010). China and Africa Envision New Security Cooperation.

http://www.hiiraan.com/news2_rss/2010/July/china_and_africa_envision_new_security_cooperation.aspx 
Scientific Research Publishing (SCIRP) is one of the largest Open Access journal publishers. It is currently publishing more than 200 open access, online, peer-reviewed journals covering a wide range of academic disciplines. SCIRP serves the worldwide academic communities and contributes to the progress and application of science with its publication.

Other selected journals from SCIRP are listed as below. Submit your manuscript to us via either submit@scirp.org or Online Submission Portal.
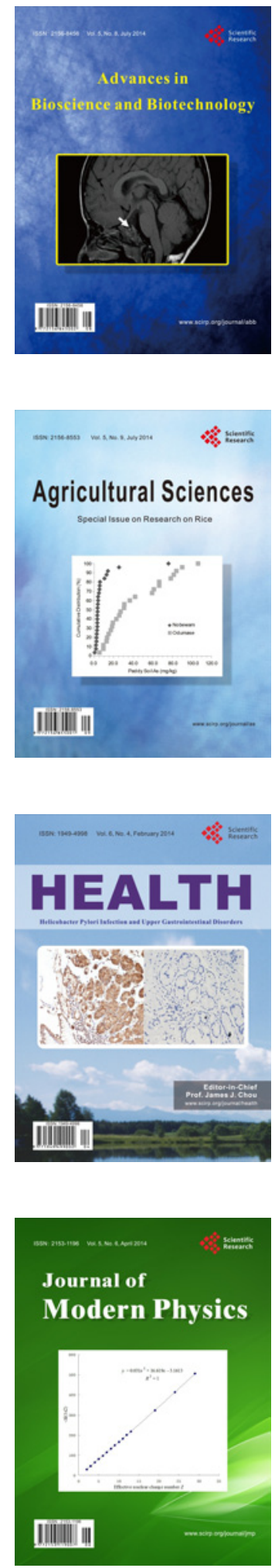
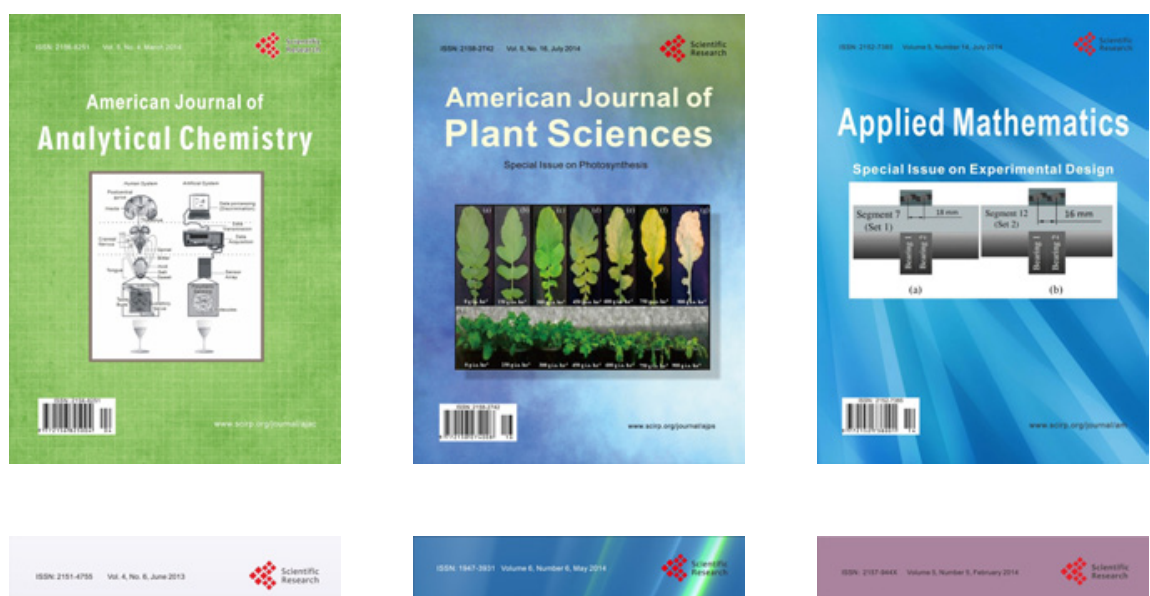

Creative Education
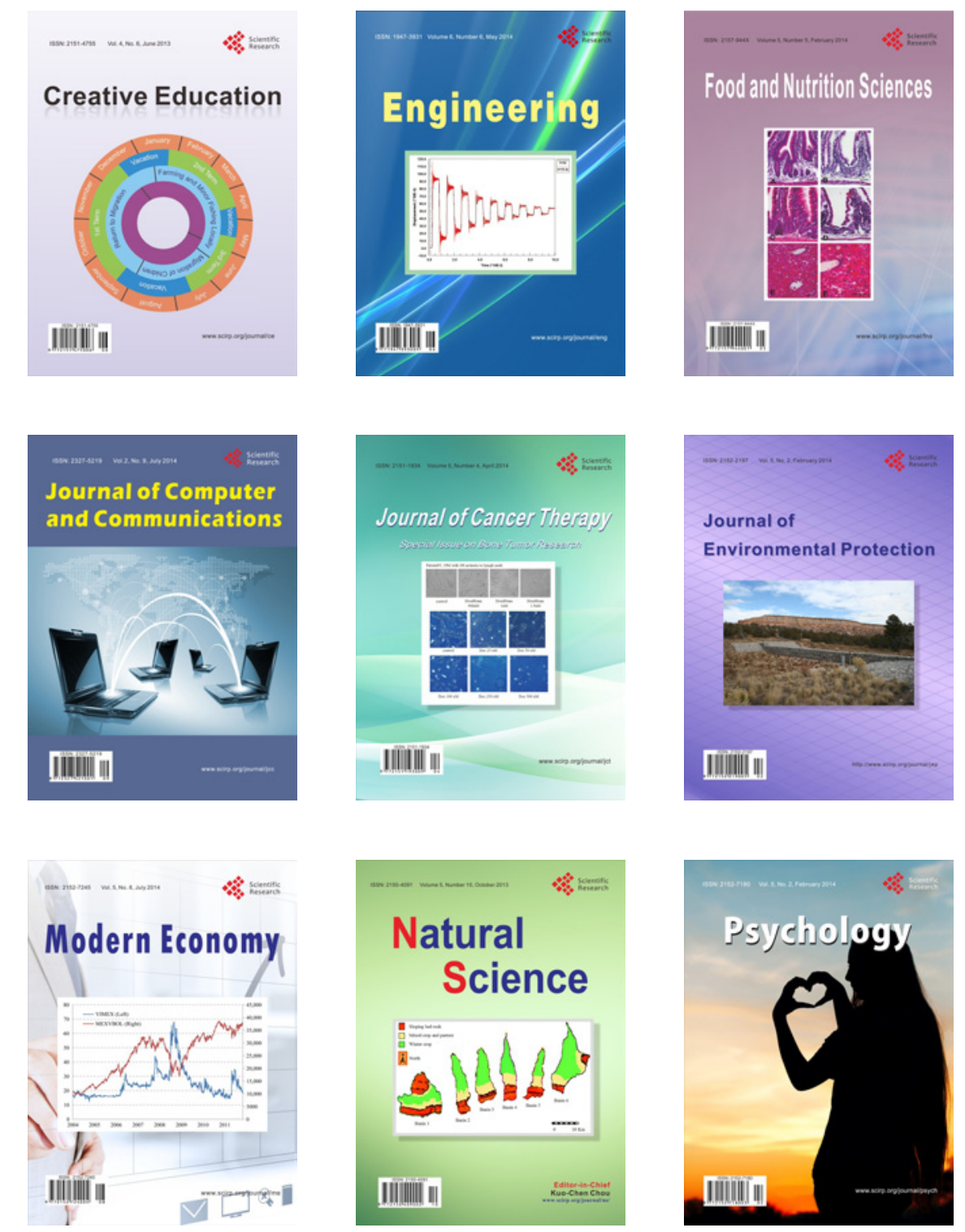